\title{
EMPLOYEE PERFORMANCE IMPROVEMENT THROUGH RELIGIOUS VALUES AND QUALITY OF COMMUNICATIONS AS WELL AS PERSONAL INTEGRITY (Case Study in PoLSUSKA Daop 5 Purwokerto)
}

\author{
Achmad Zahid*
}

* Affiliation:

Manager of PAM OPKA DAOP 6, Yogyakarta, Indonesia

achmadzahid@gmail.com

\begin{abstract}
:
The purpose of this study is to examine a model in which religious values and communication quality predict personal integrity and employee performance. A total of 129 respondents fromPolsuska Daop 5 Purwokertocompleted questionnaires. Results from structural equation modeling based smartPLS 3.0 confirmed that religious values and communication quality were positively related to personal integrity and employee performance. Furthermore, the result revealed that personal integrity was positively related to employee performance.
\end{abstract}

Keywords: Religious values, Communication quality, Personal integrity, Employee performance

\section{INTRODUCTION}

The behavior of employees in the workplace is strongly influenced by a number of factors, such as family values, religion, level of education, gender, culture, nationality, and also the community/society. When religious values and business goals met within the Organization, it will often produce unique dynamics. Religious values associated with a particular religious tradition strongly influenced the way of thinking and behaving in employees, including their attitude in establishing interpersonal relations and communication in organizations (Barro and McCleary, 2006).

In a dynamic environment, gain a competitive advantage is one of the main goals for the success of an organization. A number of organizations recognize this as their highest aspirations in order to survive in the environment changes dramatically. To achieve its objectives, the organization relies heavily on employees who appear more effective, efficient, dedicated, have integrity, religious values and high motivated. In the last 20 years, there is increasing attention to the diversity of religious values in the organization. The results of the research show that values religious diversity have a positive influence on economic growth, production, ideas, skills and work experience (Alesina et al., 2016). The diversity of individual religious values can help promote innovation or productivity of work because people with religious values of different cognitive abilities can use them to solve problems. 
Furthermore, existing research has focused on the influence of religious values diversity and economic development in cross-country comparisons.

Employee religious values can serve as personal resources are very important to maintain or protect themselves from the emergence of a sense of anxiety-related jobs. When the level of the employee's religious values are high, then a sense of anxiety related job be reduced, which has positive consequences for the performance of their duties (De Clercq et al., 2017). Religious values capable of providing guidance, encouragement, and support to employees in completing their best performance. Furthermore, religious individuals tend to have pro-social beliefs and engage in totality in the conduct of social pro-than individuals who do not have religious values (Putnam and Campbell, 2012).

Based on the existence of gaps in the research, namely the results of research conducted by Inosaria (2014) that found that religious values have a significant influence on the performance of employees. It is also supported by some research (like Darto et al., 2015; Zahrah et al., 2016), which also found that having a significant influence on the performance of employees.

However, the results of the above research findings with contradictory Osman-Gani et al. (2013), which found that religious values are not significant effect on the performance of employees. This is caused by the lack of realization of religious values (such as the activities of prayer) and employee morale so that they are not capable of showing the best performance.

Given the existence of inconsistent findings from some researchers, then increasingly encourage authors to do more research to confirm and elaborate on the relationship between religious values and the performance of employees. Based on the foregoing, the formulation of the problem in this research is the "How is the effort to improve the performance of Employees through Religious values and quality of Communications as well as Personal Integrity?".

\section{LITERATURE REVIEW Employee Performance}

Employee performance is one of the most important things that have a relationship with the achievement of the objectives of the Organization so that considerable attention by some organizations. The performance of the employee has been declared a work light (light of work) employee in doing work and their task in completing (Al-Ahmadi, 2008).

Tsui et al. (1997) emphasize that performance measurement should involve eleven indicators, namely (1) the quality of work; (2) the quantity of work; (3) the efficiency of the work; (4) the standard work; (5) the effort even harder; (6) employees have high professional standards; (7) the ability of employees in carrying out the work of the core; (8) the ability of employees to use common sense; (9) the appropriateness of the employee in performing the work of the core; (10) the ability of employees with regard to the work of the core; and (11) the creativity of employees in doing the work of the core.

\section{Personal Integrity}

Integrity is seen in personal and social to describe the strength of character and the virtues of the individual. Schlenker (2008) define integrity as degrees where someone 
personally committed to principled ethical in ideology, which in turn determines the strength of the connection between the conviction and the person's ethical behavior. Some other researchers also agree that integrity is the suitability (congruity) between the words and actions of someone (Simons, 2008). But according to Simons (2002), integrity means the person's behavior is consistent with the values and beliefs that the person is being honest and trustworthy.

Integrity combines a number of different elements, which essentially involves reflection (reflection) about how to develop and unify the values (values) (ask the difficult question of values), sincerity (sincerity ) to publicly acknowledge what is held (give answers honestly and General), and willingness (willpower) to ensure the outcome of the reflection which is manifested in the form of the character and the real action (live with the answer). By combining the four key elements of personal integrity (i.e., values, reflection, sincerity, and willpower), then a comprehensive integrity framework can incorporate many of the insights of the theory before (Music et al., 2015).

\section{Religious Value}

Koenig et al. (2012) defines values as religious beliefs, practices, rituals and symbols are well-organized designed (a) to facilitate the proximity of the sacred or transcendent (God, a higher power, or truth/ the highest reality), and (b) to foster an understanding of the relationships and responsibilities of a person to another person in living together in a community. Meanwhile, according to Al-Goaib (2003) that in Islam, religious values is a commitment to the fundamentals of Islam through practice and theoretical beliefs with compliance against the rights of God, to follow the commandments of God, protect the rights of others, avoid bad deeds, and conduct worship. Individuals who are characterized as religious people who are not only those who hold certain religious beliefs but also practice it in everyday life.

Religious values reflect the extent to which the faith or belief of individuals in holding the teachings of God, making it as supervisor and supporters, as well as apply it in their life (Eaves et al., 2008). This shows that people can defend themselves with either of the various tensions when they believe something valuable from themselves will continue even after they have experienced physical death, as informed in the teaching of religion.

There is a lot of literature that indicates that there is a significant influence among religious values, spirituality and work productivity in the lives of employees. This includes the way employees in life, behave, and it works. Religious belief can make a significant difference in the behavior and performance of employees, and provide a frame of reference that is used to guide decision-making, especially in multicultural environments and multireligious (OsmanGani et al., 2013). Furthermore, religious values also affect a wide range of phenomena relevant to the workplace, ranging from attitude to work up to ethical decision making and organizational citizenship behavior (Parboteeah et al., 2009).

Research results Zahra et al. (2016) found that religious values significant effect on the performance of employees. The higher the employee's religious values, then their performance the better. It is also supported by research Darto et al. (2015); Inosaria (2014) which concluded that religious values are also a positive and significant effect on the performance of employees. 
Based on the literature review and research before, then the hypothesis presented in this study are as follows:

\section{H1: Influential religious values significantly to employee performance}

H2: Influential religious values significantly to the integrity of the personal

The integrity of the individual can create a shared consensus in an organization. This, in turn, will create a work environment that is highly valued and full of meaning, which the Organization will operate with a focus on customers, employees, and investors in the long run. As a result, organizations will be superior in terms of performance when compared to other organizations. Integrity is seen as the key to effective business leaders (Leroy et al., 2012). In addition, the perception regarding the integrity of the leaders has a great influence on the attitude of the employees. When leaders showed greater integrity, then the employees are more satisfied with their jobs, showed the best performance, and they are more committed to the Organization (Elsetouhi et al., 2018; Vogelgesang et al., 2013).

Based on the literature review and research before, then the hypothesis presented in this study are as follows:

\section{H3: The personal integrity of the significant effect on the performance of employees}

\section{Communication Qualiry}

Communication can be defined as the exchange of information, which occurs through verbal and nonverbal channels (e.g., email), between two or more (Mesmer-Magnus and DeChurch, 2012). The size of communication generally captures the extent to which the Member is involved in the communication process feel that information received from other members is unclear, and the extent to which knowledge is shared (Hoch and Kozlowski, 2014). In particular, the communication is assumed as a tool to improve performance through facilitation, coordination, and formulation of strategies of member organizations to achieve the goals set.

According to Fletcher and Major (2006), has the main purpose of communication that is not only to clarify the misunderstandings among members of the Organization but also serves as a channel of information exchange, every individual can distribute important information to other individuals. Furthermore, communication allows individuals to receive information relating to the work environment and situational factors that can affect the nature and demands of the task (MacMillan et al., 2004). In addition, the communication also helps in the development team, which in turn is able to push high performancei.

Effective and efficient communication is very important to achieve the objectives of the Organization are sustainable. High-quality communication, which woke up among members of the Organization became the main center for building trust and mutual understanding related needs and values work expected, and to set the decision-making process combining approaches, goals, and expectations are agreed upon (Paget et al., 2011).

High-quality communication in General related to job satisfaction and encouraging the improvement of the quality of work of employees. Research results Romá and GonzálezHernández (2014); He et al. (2007); Marlow et al. (2018) found that the quality of communication 
in the work of the team has a very strong influence and significantly to the performance of the employee.

Other researchers have shown that the effectiveness of communication is the main indicator of the success of organizations (Ruck and Welch, 2012). According to Meng and Berger (2012), values that are created through good communication in organizations are often oriented in the future, such as recommendations and potential growth in investor opportunities. Similarly, Jiang and Men (2017) asserts that communication quality, transparent and consistent management is important drivers of employee involvement.

Based on the literature review and research before, then the hypothesis presented in this study are as follows:

H4: Influential communications quality significantly to the integrity of thepersonal H5: The quality of the communication effect significantly to employee performance

Based on the literature review and empirical research conducted by experts, the model of empirical research that was built in this study is:

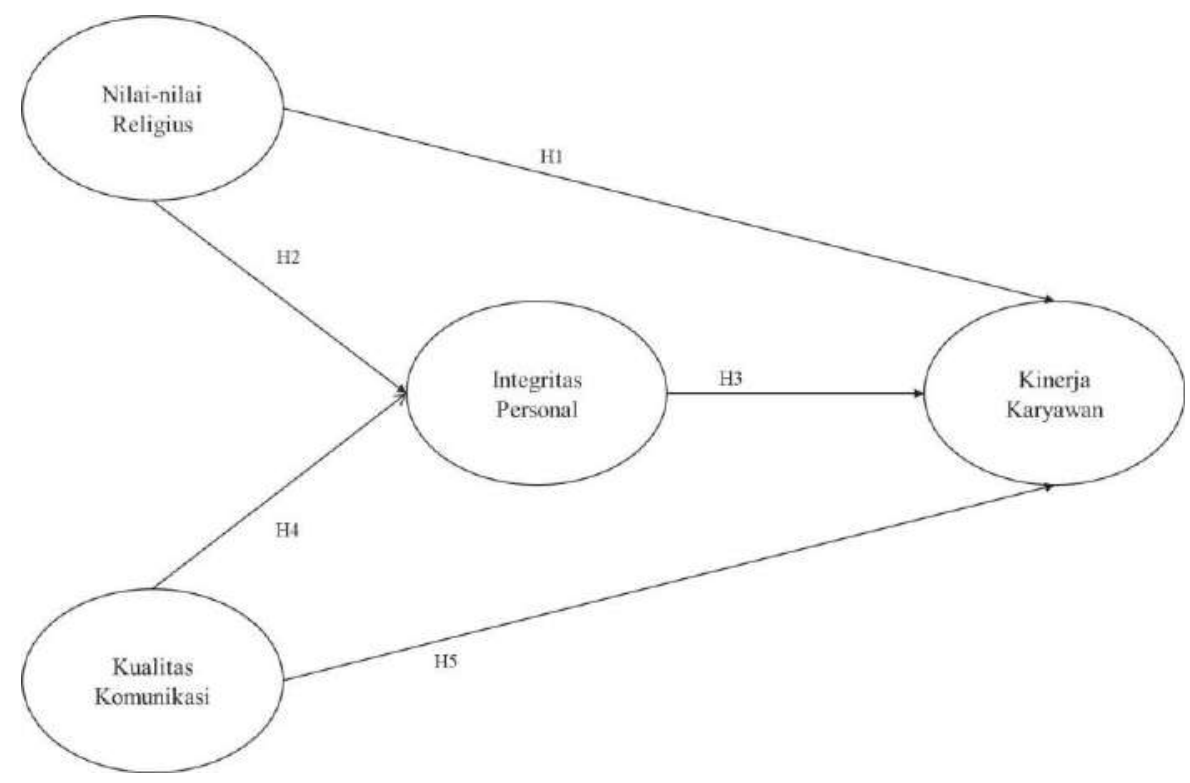

Figure 1 Empirical Research Model

\section{RESEARCH METHOD}

The population in this research is the entire Polsuska clerk Daop 5 Purwokerto totaling 129 people. Sampling method in this research is to use "census "i.e. the entire population is used as a sample study, which amounted to 129 people.

In order to test the hypothesis, data analysis in this study uses the Partial Least Square (PLS). PLS is a powerful method of analysis because it does not assume that the data must be measured with the measurement of a certain scale, can be applied to all the data, the scale does not require a lot of assumptions, and the sample size may not be large. 


\section{RESULT AND DISCUSSION}

\section{Test validity and Reliability}

The result of data processing of the loadings of the outer using SmartPLS 3 is:

Table 1 Outer Loadings

\begin{tabular}{|l|l|l|l|l|}
\hline & $\begin{array}{c}\text { Personal } \\
\text { Integrity }\end{array}$ & $\begin{array}{c}\text { Employee } \\
\text { Performance }\end{array}$ & $\begin{array}{c}\text { Communication } \\
\text { Quality }\end{array}$ & $\begin{array}{c}\text { Religious } \\
\text { Value }\end{array}$ \\
\hline IP1 & 0,818092 & & & \\
\hline IP2 & 0,748098 & & & \\
\hline IP3 & 0,636910 & & & \\
\hline IP4 & 0,621143 & & & \\
\hline IP5 & 0,818147 & & & \\
\hline KK1 & & 0,585062 & & \\
\hline KK2 & & 0,722955 & & \\
\hline KK3 & & 0,686620 & & \\
\hline KKOM1 & & & 0,516886 & \\
\hline KKOM2 & & & 0,753186 & \\
\hline KKOM3 & & & 0,674048 & \\
\hline KKOM4 & & & 0,753292 & \\
\hline KKOM5 & & & 0,731873 & \\
\hline NNR1 & & & & 0,516400 \\
\hline NNR2 & & & & 0,886927 \\
\hline NNR3 & & & & 0,895468 \\
\hline NNR4 & & & & \\
\hline NNR5 & & & & 0,890837 \\
\hline
\end{tabular}

From table 1 it can be noted that the correlation of invalid constructs religious values, the quality of communication, personal Integrity, and the performance of employees with each charge indicators will be higher above 0.5 , so the invalid constructs in the model being estimated meet discriminant validity criteria.

Table 2 Composite Reliability

\begin{tabular}{|l|c|}
\hline & Composite Reliability \\
\hline Personal Integrity & 0,851691 \\
\hline Employee Performance & 0,705150 \\
\hline Communication Qualiry & 0,818479 \\
\hline Religious Value & 0,911685 \\
\hline
\end{tabular}


Table 2 shows that the value of composite reliability to all invalid constructs is above 0.7 indicating that all invalid constructs in the model being estimated meet criteria reliability.

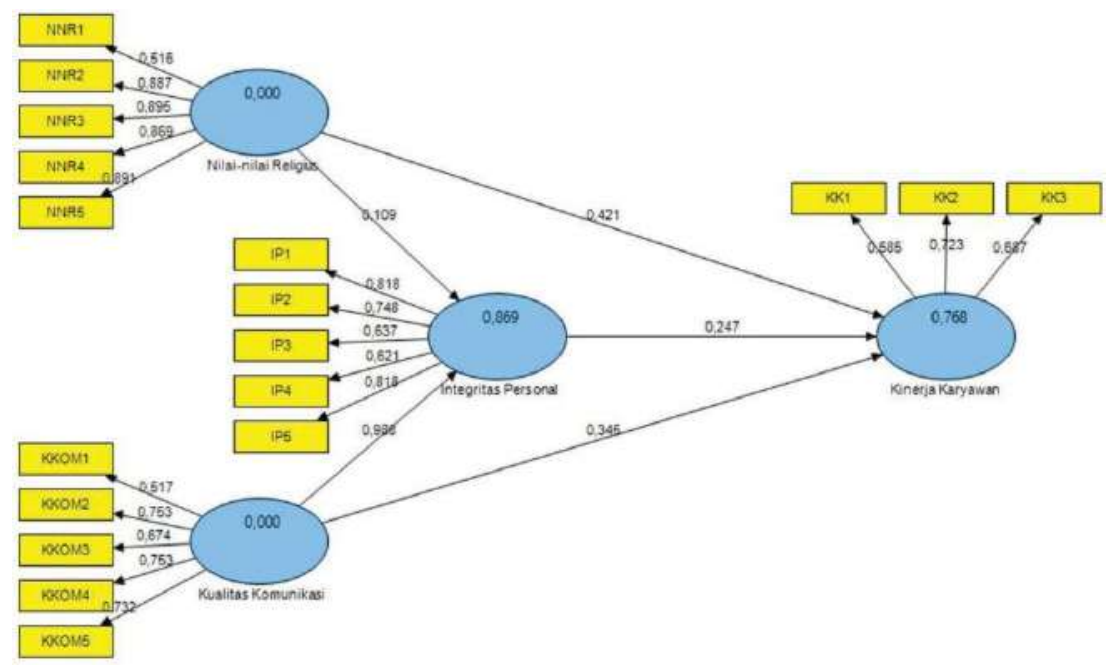

Figure 2 Structural Model

Tabl 3 R-Square

\begin{tabular}{|l|l|}
\hline & R Square \\
\hline Personal Integrity & 0,869373 \\
\hline Employee Performance & 0,768258 \\
\hline Communication Quality & \\
\hline Religious Value & \\
\hline
\end{tabular}

Based on table 3 shows the R-square value invalid constructs personal Integrity of 0.869 meaning that religious values and the quality of communication is able to explain the personal integrity of the variance of $86.9 \%(13.1 \%)$ and the rest influenced by other factors not examined in this study. The next value of the R-square is also present on the employee's Performance i.e. invalid constructs of 0.768 meaning that religious values, the quality of communication, and personal Integrity are able to explain the variance of performance of employees of $76.8 \%$ and the remainder $(23.2 \%)$ influenced by other factors not examined in this study.

Table 4Path Coefficients

\begin{tabular}{|l|c|c|c|c|c|}
\hline & $\begin{array}{c}\text { Original } \\
\text { Sample }\end{array}$ & $\begin{array}{c}\text { Sample } \\
\text { Mean }\end{array}$ & $\begin{array}{c}\text { Standard } \\
\text { Deviation }\end{array}$ & $\begin{array}{c}\text { Standard } \\
\text { Error }\end{array}$ & T Statistics \\
\hline Religious Value $\rightarrow$ Employee Performance & 0,420948 & 0,423574 & 0,056363 & 0,056363 & 7,468501 \\
\hline Religious Value $\rightarrow$ Personal Integrity & 0,108845 & 0,103418 & 0,040668 & 0,040668 & 2,676457 \\
\hline Personal Integrity $\rightarrow$ Employee Performance & 0,247476 & 0,241533 & 0,124844 & 0,124844 & 1,982277 \\
\hline Communication Quality $\rightarrow$ Personal Integrity & 0,988362 & 0,986639 & 0,020021 & 0,020021 & 49,367102 \\
\hline $\begin{array}{l}\text { Communication Quality } \rightarrow \text { Employee } \\
\text { Performance }\end{array}$ & 0,344812 & 0,350243 & 0,129722 & 0,129722 & 2,658078 \\
\hline
\end{tabular}


Based on a test of relations between invalid constructs in table 4, then the hypothesis presented in this research can be described as follows:

\section{The influence of Religious values on the performance of employees}

The first hypothesis put forward in the study was "the most influential religious values significantly to the performance of the employee". Table 4 shows that the relationship between the religious values to the performance of the employee was a positive significant effect because the value of the statistic is greater than $t$ table (statistic 7.468501 > t table 1.66) at 5\% significance level. Thus, the first hypothesis stating "influential religious values significantly to the performance of the employees" are acceptable.

Religious values promote virtue in giving, sharing, and sacrifice for the good of holistically. This also applies to the religion of Islam. Islamic law, known as Sharia, is the code which regulates tasks, morals, and behavior of all Muslims, either collectively or individually, in all aspects of life. Sharia describes the values that should be owned by the Muslims, including truth, honesty, duty, and social responsibility, as well as the role of men and women. The religious values of Islam focused on morality and refinement of higher value, which is contrary to the nature of individualism related to materialism as jealousy, envy, greed, and lack of generosity (Adib and El-Bassiouny, 2012).

McGuire et al. (2012) also found that religious values are high can rein in managers from unethical business practices and improve the efficiency of the Organization's operational cost control. Furthermore, the managers of which have religious values are high prefer real earnings management rather than accrual manipulation. Ho et al. (2016) also in their findings prove that religious values are able to promote the experience of connectedness, spirituality, wealth and well-being holistically.

The results of this study are consistent with the findings of the Zahra et al. (2016) that found that religious values significant effect on the performance of employees. The higher the employee's religious values, then their performance the better. It is also supported by research Darto et al. (2015); Inosaria (2014) that proves that religious values are a very positive and significant effect on the performance of employees.

\section{The influence of Religious values against Personal Integrity}

The second hypothesis put forward in the study was "the most influential religious values significantly to personal integrity". Based on Table 4.14 shows that the relationship between the religious values personal integrity is a significantly positive effect because the value of the statistic is greater than $t$ table (statistic $2.676457>t$ table 1.66) at 5\% significance level. Thus, the second hypothesis stating "influential religious values significantly to personal integrity" are acceptable.

Religious values guide individuals in their lives through the process. Islam is a religion which is believed to have a very strong influence on the Muslim community in all areas of life (Kavoossi, 2000). Therefore, if a person believes in the necessity of religious values, he also received religious teachings about how to live his life fully and commitment to religious values that are believed to be. Tang (2016) affirmed that religious values do not only affect individual values, ethical assessment, ethical beliefs, and attitudes but also aims to prevent a form of deviant behavior. 
The results of this research in line with the findings of the Tong and Teo (2018) that religious values to increase positive emotions so that individuals always perform with integrity. Chen et al. (2014) also reported that religious values have a stronger influence in reducing the intention/unethical behavior in the Organization because the individual running the rules of their religion and live an ethical lifestyle for the sake of avoiding cognitive dissonance. When individuals are always upheld truth, mutual help and love others, then they will do the right thing, reducing the ego/personal interests, and avoid unethical behavior or hurt others.

\section{Personal Integrity against the Influence of Employee Performance}

The third hypothesis put forward in the study was "the most influential personal Integrity significantly to the performance of the employee". Based on the results of the analysis of the path's in table 4.14 shows that the relationship between employee Performance with personal Integrity is a significantly positive effect because the value of the statistic is greater than $t$ table (statistic $1.982277>\mathrm{t}$ table 1.66) at 5\% significance level. Thus, the third hypothesis in this study which stated "the integrity of personal effect significantly to the performance of the employee" is acceptable.

Personal integrity is viewed as a pattern of the perceived rapprochement between the words and the actions taken by individuals. With keeping and keep the promise has been pronounced, then an individual would easily be trusted by others. Personal integrity has significant effects on the behavior of air-ethics, extra-role behavior, and the behavior of the employees don't stray (Dineen et al., 2006). Employees who have integrity tend to perform better, showing OCB and higher organizational commitment, experience greater job satisfaction, and intend to remain in the Organization.

The integrity of the individual can create a shared consensus in an organization. This, in turn, will create a work environment that is precious and full of meaning, which the Organization will operate with a focus on customers, employees, and investors in the long run. As a result, organizations will be superior in terms of performance when compared to other organizations. Integrity is seen as the key to effective business leaders (Leroy et al., 2012). In addition, the integrity of the leaders has a great influence on the attitude of the employees. When the leader shows higher integrity, then the employees are more satisfied with their jobs, showed the best performance, and they are more committed to the Organization (Elsetouhi et al., 2018; Vogelgesang et al., 2013).

\section{The Influence Of Communication Quality Against Personal Integrity}

The fourth hypothesis put forward in the study was "the most influential communications Quality significantly to personal integrity". Based on Table 4.14 shows that the variable quality of communication effect significantly to personal Integrity because the value of the statistic is greater than $\mathrm{t}$ table (statistic $49.367102>\mathrm{t}$ table 1.66) at 5\% significance level. Thus, the fourth hypothesis proposed in this study i.e. "the quality of the communication effect significantly to personal integrity" are acceptable.

Communication involves the transmission of messages through the media. There are two very important communication components, namely the content of communication and 
forms of communication. The second component of this communication must be of high quality in order for communication to be effective.

Vogelgesang et al. (2013) prove that the employees who communicate effectively will be considered to have greater integrity (i.e. alignment of words and actions), which will encourage the involvement of interns in achieving the objectives of the organization. Furthermore, the leaders communicate effectively about the work conveys a clear signal regarding the motives and their intention to choose certain actions based on actions taken on the advice of their followers (Avolio, Walumbwa and 2006).

High-quality communication would further strengthen the integrity of the behavior of leaders, which will encourage the identification of followers to engage further in challenges to their tasks in the future (Simons, 2008). At the same time, the leaders of the integrity of the high behavior send a message (there is no contradiction between the implications of words with actions). Through words and actions, leaders maintain consistency, building greater understanding and higher involvement in the pursuit of these goals.

\section{Influence of Communication Quality on the performance of employees}

The fifth hypothesis put forward in the study was "the most influential communications Quality significantly to the performance of the employee". Based on Table 4.14 shows that significant influential variable quality of communication on the performance of employees because the value of the statistic is greater than t table (statistic $2.658078>\mathrm{t}$ table 1.66) at 5\% significance level. Thus, the fifth hypothesis which States "the quality of the communication effect significantly to the performance of the employees" are acceptable.

Effective communication between employees helps make it easier to share information and knowledge that is beneficial to one another in providing solutions to the problems encountered. Quality of communications related to the sharing and exchange of information is also able to improve the effectiveness of organizations (Tzafrir et al., 2004).

The effectiveness of communication is also considered influential on the quality of the technical and functional organization. Sharma and Patterson (1999) State that communication is an important element to achieve the high quality of the organization. With a blend of technical knowledge and ability of the communicative, it will be increasingly cemented and establish the existence of the Organization in the future. High communication skills are very necessary to ensure that employees are more confident with their ability to get involved in the Organization and to assist them in completing the various performance optimally.

The results of this study are consistent with other research findings that high-quality communication, in General, related to job satisfaction and encouraging the improvement of the quality of work of employees. Research results Romá and González-Hernández (2014); He et al. (2007); Marlow et al. (2018) found that the quality of communication in the work of the team has a very strong influence and significantly to the performance of the employee.

\section{CONCLUSION}

These studies can generally be inferred that the employee's performance can be improved through religious values, the quality of communication, and personal integrity. 
Upcoming research need to add other variables that are expected to improve the performance of employees, for example, passion for work, career satisfaction, employee-friendly culture, altruism, and ideological contract fulfillment.

\section{REFERENCES}

Adib, H., \& El-Bassiouny, N. (2012). Materialism in young consumers: An investigation of family communication patterns and parental mediation practices in Egypt. Journal of Islamic Marketing, 3(3), 255-282.

Al-Ahmadi, F. M. (2008). The development of scientific thinking with senior school physics students. University of Glasgow.

Al-Goaib, S. (2003). Religiosity and social conformity of university students: An analytical study applied at King Saoud University. Arts Journal of King Saoud University, 16(1), 51-99.

Alesina, A., Harnoss, J., \& Rapoport, H. (2016). Birthplace diversity and economic prosperity. Journal of Economic Growth, 21(2), 101-138.

Avolio, B. J., \& Walumbwa, F. O. (2006). Authentic leadership: Moving HR leaders to a higher level Research in personnel and human resources management (pp. 273-304): Emerald Group Publishing Limited.

Chen, J., Tang, T. L.-P., \& Tang, N. (2014). Temptation, monetary intelligence (love of money), and environmental context on unethical intentions and cheating. Journal of business ethics, 123(2), 197-219.

De Clercq, D., Haq, I. U., \& Azeem, M. U. (2017). Perceived threats of terrorism and job performance: The roles of job-related anxiety and religiousness. Journal of Business Research, 78, 23-32.

Dineen, B. R., Lewicki, R. J., \& Tomlinson, E. C. (2006). Supervisory guidance and behavioral integrity: Relationships with employee citizenship and deviant behavior. Journal of applied psychology, 91(3), 622 .

Eaves, L. J., Hatemi, P. K., Prom-Womley, E. C., \& Murrelle, L. (2008). Social and genetic influences on adolescent religious attitudes and practices. Social Forces, 86(4), 16211646.

Elsetouhi, A. M., Hammad, A. A., Nagm, A.-E. A., \& Elbaz, A. M. (2018). Perceived leader behavioral integrity and employee voice in SMEs travel agents: The mediating role of empowering leader behaviors. Tourism Management, 65, 100-115.

Fletcher,T.D., \& Major,D.A. (2006). The effects of communication modality on performance and self-ratings of teamwork components. Journal of Computer-Mediated Communication, $11(2), 557-576$.

González-Romá, V., \& Hernández, A. (2014). Climate uniformity: Its influence on team communication quality, task conflict, and team performance. Journal of applied psychology, 99(6), 1042. 
Hoch, J. E., \& Kozlowski, S. W. (2014). Leading virtual teams: Hierarchical leadership, structural supports, and shared team leadership. Journal of applied psychology, 99(3), 390.

Kavoossi, M. (2000). The globalization of business and the Middle East: Opportunities and constraints: Greenwood Publishing Group.

Koenig, H. G., King, D., \& Carson, V. B. (2012). Handbook of religion and health: Oup Usa.

Leroy, H., Palanski, M. E., \& Simons, T. (2012). Authentic leadership and behavioral integrity as drivers of follower commitment and performance. Journal of business ethics, 107(3), 255-264.

Marlow, S. L., Lacerenza, C. N., Paoletti, J., Burke, C. S., \& Salas, E. (2018). Does team communication represent a one-size-fits-all approach?: A meta-analysis of team communication and performance. Organizational Behavior and Human Decision Processes, 144, 145-170.

McCleary, R. M., \& Barro, R. J. (2006). Religion and economy. Journal of Economic Perspectives, 20(2), 49-72.

McGuire, S. T., Omer, T. C., \& Sharp, N. Y. (2012). The impact of religion on financial reporting irregularities. The Accounting Review, 87(2), 645-673.

Meng, J., \& Berger, B. K. (2012). Measuring return on investment (ROI) of organizations' internal communication efforts. Journal of Communication Management, 16(4), 332354.

Mesmer-Magnus, J. R., \& DeChurch, L. A. (2012). Information sharing and team performance: a meta-analysis. IEEE Engineering Management Review, 40(1), 119-136.

Osman-Gani, A. M., Hashim, J., \& Ismail, Y. (2013). Establishing linkages between religiosity and spirituality on employee performance. Employee relations, 35(4), 360-376.

Paget, L., Han, P., Nedza, S., Kurtz, P., Racine, E., Russell, S., \& Von Kohorn, I. (2011). Patient-clinician communication: Basic principles and expectations. Washington, DC: IOM Working Group Report, Institute of Medicine.

Putnam, R. D., \& Campbell, D. E. (2012). American grace: How religion divides and unites us: Simon and Schuster.

Ruck, K., \& Welch, M. (2012). Valuing internal communication; management and employee perspectives. Public Relations Review, 38(2), 294-302.

Schlenker, B. R. (2008). Integrity and character: Implications of principled and expedient ethical ideologies. Journal of Social and Clinical Psychology, 27(10), 1078.

Sharma, N., \& Patterson, P. G. (1999). The impact of communication effectiveness and service quality on relationship commitment in consumer, professional services. Journal of services marketing, 13(2), 151-170. 
Simons, T. (2002). Behavioral integrity: The perceived alignment between managers' words and deeds as a research focus. Organization Science, 13(1), 18-35.

Simons, T. (2008). The integrity dividend: Leading by the power of your word: John Wiley \& Sons.

Tong, E. M., \& Teo, A. Q. (2018). The influence of religious concepts on the effects of blame appraisals on negative emotions. Cognition, 177, 150-164.

Tsui, A. S., Pearce, J. L., Porter, L. W., \& Tripoli, A. M. (1997). Alternative approaches to the employee-organization relationship: Does investment in employees pay off? Academy of Management journal, 40(5), 1089-1121.

Tzafrir, S. S., Harel, 1. G. H., Baruch, Y., \& Dolan, S. L. (2004). The consequences of emerging HRM practices for employees' trust in their managers. Personnel Review, 33(6), 628647.

Vogelgesang, G. R., Leroy, H., \& Avolio, B. J. (2013). The mediating effects of leader integrity with transparency in communication and work engagement/performance. The Leadership Quarterly, 24(3), 405-413.

Zahrah, N., Hamid, S. N. A., Rani, S. H. A., \& Kamil, B. A. M. (2016). Enhancing Job Performance through Islamic Religiosity and Islamic Work Ethics. International Review of Management and Marketing, 6(7S) 